\author{
Doi 10.5943/ppq/8/2/4 \\ Copyright $\odot$ Agriculture College, Guizhou University
}

\title{
A new morphotype of Golovinomyces neosalviae infecting Salvia officinalis
}

\author{
Götz $\mathbf{M}^{1}$, Idczak $\mathbf{E}^{1}$, Richert-Pöggeler $\mathrm{K}^{2}$ and Braun $\mathbf{U}^{3}$ \\ ${ }^{1}$ Institute for Plant Protection in Horticulture and Forests, JKI Julius Kühn-Institute Federal Research Centre for \\ Cultivated Plants, Messeweg 11/12, D-38104 Braunschweig, Germany \\ ${ }^{2}$ Institute for Epidemiology and Pathogen Diagnostics, JKI Julius Kühn-Institute Federal Research Centre for \\ Cultivated Plants, Messeweg 11/12, D-38104 Braunschweig, Germany \\ ${ }^{3}$ Institute of Biology, Geobotany and Botanical Garden, Herbarium, Marthin Luther University, Neuwerk 21, D-06099 \\ Halle/Saale, Germany
}

Götz M, Idczak E, Richert-Pöggeler K, Braun U 2018 - A new morphotype of Golovinomyces neosalviae infecting Salvia officinalis. Plant Pathology \& Quarantine 8(2), 131-139, Doi $10.5943 / \mathrm{ppq} / 8 / 2 / 4$

\begin{abstract}
In 2017, severe powdery mildew infections of Salvia officinalis were observed at two locations in Germany. Two powdery mildew strains were isolated and molecularly and morphologically characterized. Based on ITS-28S rRNA sequences both isolates were assigned to the recently described Golovinomyces neosalviae. While mycelium and conidial features did not differ from each other and were in accordance with those described before for G. neosalviae, conidiophores were considerably different from any earlier descriptions suggesting the occurrence of a new morphotype. Conidiophores were very variable and up to $800 \mu \mathrm{m}$ long, often with shoulder-like swellings. Moreover, they showed single or multiple branching which has not yet been described for Golovinomyces species.
\end{abstract}

Key words - branched conidiophores - conidia - morphology - powdery mildew - sage

\section{Introduction}

Saliva officinalis, also known as common sage, is native to the northern coastal area of the Mediterranean region and is grown worldwide as one of the most popular aromatic plants used as a medicinal plant and culinary herb as well as an ornamental. In Germany, S. officinalis is cultivated in the field mainly for medicinal and cosmetic purposes on an area of more than 40 ha (Anon. 2014). Furthermore, it is produced under greenhouse conditions and on beds in nurseries.

In 2017, severe powdery mildew infections were observed on several cultivars of S. officinalis produced in organic farming in greenhouses and in outdoor beds in a nursery in Riddagshausen. Powdery mildew infections were also found in a field near Freital. Morphological examination revealed extremely long and branched conidiophores that were not described before for powdery mildews found on S. officinalis (Cabrera et al. 2010, Braun \& Cook 2012, Scholler et al. 2016).

The aim of this study was to further characterize the powdery mildew isolates of both locations molecularly and morphologically to verify their species affiliation and to analyze and characterize the new morphotype. 


\section{Materials \& Methods}

\section{Collection and maintenance of powdery mildew isolates}

Powdery mildew isolates were collected from infected Salvia officinalis plants at two locations in July 2017 (Table 1).

Table 1 Identifier of Golovinomyces neosalviae isolates, host plant and locations where isolates were collected in July 2017, and GenBank accession number of ITS1, 5.8S rRNA, ITS2, 28S rRNA complete and partial sequences.

\begin{tabular}{lllll}
\hline $\begin{array}{l}\text { Isolate } \\
\text { identifier }\end{array}$ & Host plant & Location & Coordinates & $\begin{array}{l}\text { GenBank } \\
\text { accession number }\end{array}$ \\
\hline JKI-GF-C20- & $\begin{array}{l}\text { Salvia officinalis } \\
\text { EM16 }\end{array}$ & $\begin{array}{l}\text { Freital, Saxony, } \\
\text { 'Freitaler Auswahl' }\end{array}$ & $\begin{array}{l}\text { Nermany } \\
\text { E13.017919 }\end{array}$ & MG3866701 \\
JKI-GF-C20- & $\begin{array}{l}\text { Salvia officinalis } \\
\text { EM18 }\end{array}$ & $\begin{array}{l}\text { Riddagshausen, } \\
\text { 'Cower Saxony, } \\
\text { Germany }\end{array}$ & $\begin{array}{l}\text { N52.268475 } \\
\text { E10.576772 }\end{array}$ & MG386700 \\
\hline
\end{tabular}

Plants of the susceptible Salvia officinalis 'Cleres' (Hild Samen GmbH, Germany) were kept as host plants in a greenhouse at $20{ }^{\circ} \mathrm{C}$ and a natural day/night interval. To produce and maintain single spore isolates of the powdery mildew fungi, fully expanded leaves were carefully washed with tap water and transferred onto a grid in a transparent plastic box with a water reservoir taking care that the petioles were submerged in the water. Single conidia or conidial chains were transferred onto the washed leaves using an eyelash. To ensure pure isolates, four subsequent subcultures were performed. Boxes were incubated at $20 \pm 2{ }^{\circ} \mathrm{C}$ and natural day/night interval. Not inoculated leaves served as controls.

\section{Molecular characterization}

Total DNA was extracted from conidia and mycelia using the DNeasy plant mini kit (Qiagen $\mathrm{GmbH}$, Germany) following the manufacturer's instructions with slight modifications. The 5'-end of the 28S rRNA and internal transcribed spacer (ITS) was amplified using the primers ITS5 and PM6 (Takamatsu \& Kano 2001) for ITS fragment and PM5 (Takamatsu \& Kano 2001) and NLP2 (Hirose et al. 2005) for 28S rRNA. The reaction mix contained Hot FirePol Mastermix (containing $7.5 \mathrm{mM} \mathrm{MgCl} 2$, Solis BioDyne), $0.2 \mu \mathrm{M}$ of each primer and $4 \mu 1$ template DNA in a total volume of $50 \mu \mathrm{l}$. PCR was performed in a MyCycler (Bio-Rad Laboratories, Austria) with an initial denaturation step at $95{ }^{\circ} \mathrm{C}$ for $13 \mathrm{~min}$ followed by 40 cycles of $30 \mathrm{~s}$ at $94{ }^{\circ} \mathrm{C}$ for denaturation, 30 $\mathrm{s} / 50 \mathrm{~s}$ (ITS/28 S rRNA) at $52{ }^{\circ} \mathrm{C}$ for annealing, $30 \mathrm{~s} / 50 \mathrm{~s}$ (ITS/28 S rRNA) at $72{ }^{\circ} \mathrm{C}$ for extension and a final extension for $10 \mathrm{~min}$ at $72{ }^{\circ} \mathrm{C}$. PCR products were purified (MSB Spin PCRapace Kit, Stratec Biomedical AG, Germany). Fragments were sequenced for each primer pair twice in each direction (LGC Genomics GmbH, Germany). Contigs were generated and edited using CLC Main Workbench 7.9.1 (Qiagen, Germany) following the EPPO recommendations for sequence analysis (OEPP/EPPO 2016). Consensus sequences were deposited in GenBank (Table 1).

Sequences obtained for both isolates were aligned to sequences of Golovinomyces neosalviae, G. salviae, G. biocellatus and additional sequences of Golovinomyces spp. available in GenBank using CLC Main Workbench 7.9.1 with the settings gap open cost 10.0 and gap extension cost 1.0 and the very accurate alignment mode. The outgroup taxon, Golovinomyces magnicellatus (AB769441) was chosen in accordance with Scholler et al. (2016). Alignments were manually refined using CLC Main Workbench.

A phylogenetic tree was constructed using the Neighbor-Joining method and the nucleotide substitution model Kimura 80 with a transition/transversion ratio of 2.0. The strength of the internal branches of the resulting tree was tested with bootstrap analysis using 1000 replications (CLC Main Workbench 7.9.1). 


\section{Morphological characterization}

For morphological characterization, fresh powdery mildew structures were stripped off the leaf surface with clear adhesive tape, mounted on a microscope slide with the fungal mycelium facing the top. The tape was covered with sterile tap water and a coverslip. Morphological characteristics covering size and shape of conidia $(n \geq 60)$ and conidiophores $(n \geq 50)$, position of the basal septum, shape and position of hyphal appressoria and presence or absence of fibrosin bodies were assessed for each isolate. Conidial length and width were analyzed following Frank (1990) with modifications: the five values indicating the minimum, lower limit, arithmetic mean, upper limit and maximum value, respectively; lower and upper limits indicate the range of $90 \%$ of all values.

All morphological characteristics were examined using a standard light microscope (Axio Imager.A1 equipped with an AxioCam MRc5 camera, Zeiss, Germany) and differential interference contrast at magnifications $200 \times, 400 \times$, and $1000 \times$. Measurements were made and images were taken with the calibrated Axiovision software rel. 4.8 (Zeiss, Germany), and the images were processed using Adobe Photoshop CS4 software version 11.0 (Adobe Systems, USA).

Conidial germination patterns were assessed following the method of Zaracovitis (1965) with slight modifications. Preferably young conidia $(\sim 24 \mathrm{~h})$ were dusted onto microscope slides and incubated in a moist chamber at $20 \pm 1{ }^{\circ} \mathrm{C}$ in the dark for $24-48 \mathrm{~h}$. Analysis and documentation was done as described before.

For SEM, conidia were dusted onto conductive double-sided adhesive tape on aluminum stubs. Specimens were analyzed immediately or incubated as described above to evaluate germination patterns. Samples were examined directly in low vacuum at $80 \mathrm{~Pa}$ using a Quanta 250 scanning electron microscope (FEI Deutschland $\mathrm{GmbH}$, Germany) with an emission current of $65 \mu \mathrm{A}$ at $12.5 \mathrm{kV}$ with a scan speed of $60 \mu \mathrm{s}$. Images were processed using Adobe Photoshop CS4 software version 11.0.

\section{Results}

\section{Phylogenetic analysis}

Sequence data including genes for ITS1, 5.8S rRNA, ITS2, 28S rRNA (partial and complete) obtained from the isolates JKI-GF-C20-16 (MG386701) and JKI-GF-C20-18 (MG386700) showed only a single nucleotide exchange.

The sequences were used for phylogenetic analyses including all sequences presently available for $G$. neosalviae (8) and $G$. salviae (2) in GenBank, selected sequences from $G$. biocellatus (7) and G. monardae (5). G. magnicellatus was used as the outgroup species.

Sequences of JKI-GF-C20-16 and JKI-GF-C20-18 clustered in the G. neosalviae clade confirming that both isolates have to be assigned to this species (Fig. 1).

\section{Morphological description}

Macroscopic infection characteristics and symptom development of the isolates $G$. neosalviae JKI-GF-C20-EM16 and JKI-GF-C20-EM18 did not differ from each other. Infection started with white mainly epiphyllous colonies with irregular margins (Fig. 2a, b). As the disease progressed, dense white patches were observed which merged during disease development and finally could cover the whole leaf surface (Fig. 2c). Colonies were observed on upper and lower leaf surface (but more pronounced epiphyllously), on petioles and on stems. Heavily infected leaves became yellowish and were finally shed.

Microscopic analysis revealed that morphological characteristics of $G$. neosalviae JKI-GFC20-EM16 and JKI-GF-C20-EM18 did not differ considerably from each other (Table 2).

Hyphae were branched, septate, 2-7 $\mu \mathrm{m}$ wide, colorless, thin-walled and smooth; hyphal appressoria were rare, in general solitary and nipple-shaped. The conidiophores of both isolates were very variable. No differences between epiphyllous and hypophyllous conidiophores were observed. They emerged on top of mother cells, straight or slightly curved, some very long (Figs 
$3 \mathrm{a}, 4 \mathrm{a})$ and $8-14 \mu \mathrm{m}$ wide, erect or curved at the base, central on mother cell or formed about $1 / 3-$ $2 / 3$ or $1 / 4-3 / 4$ towards one end of the mother cells, basal septum of the foot-cells raised 2-25 $\mu \mathrm{m}$ above junction with mother cell, size and arrangement of cells very variable, mostly at the base with 1-3 cells 31-77 $\mu \mathrm{m}$ long, followed by the longest cell of $100-248 \mu \mathrm{m}$, and then $0-3$ shorter cells or, rarely, foot-cell being the longest cell of conidiophores, followed by 1-3 shorter cells, forming catenescent conidia.

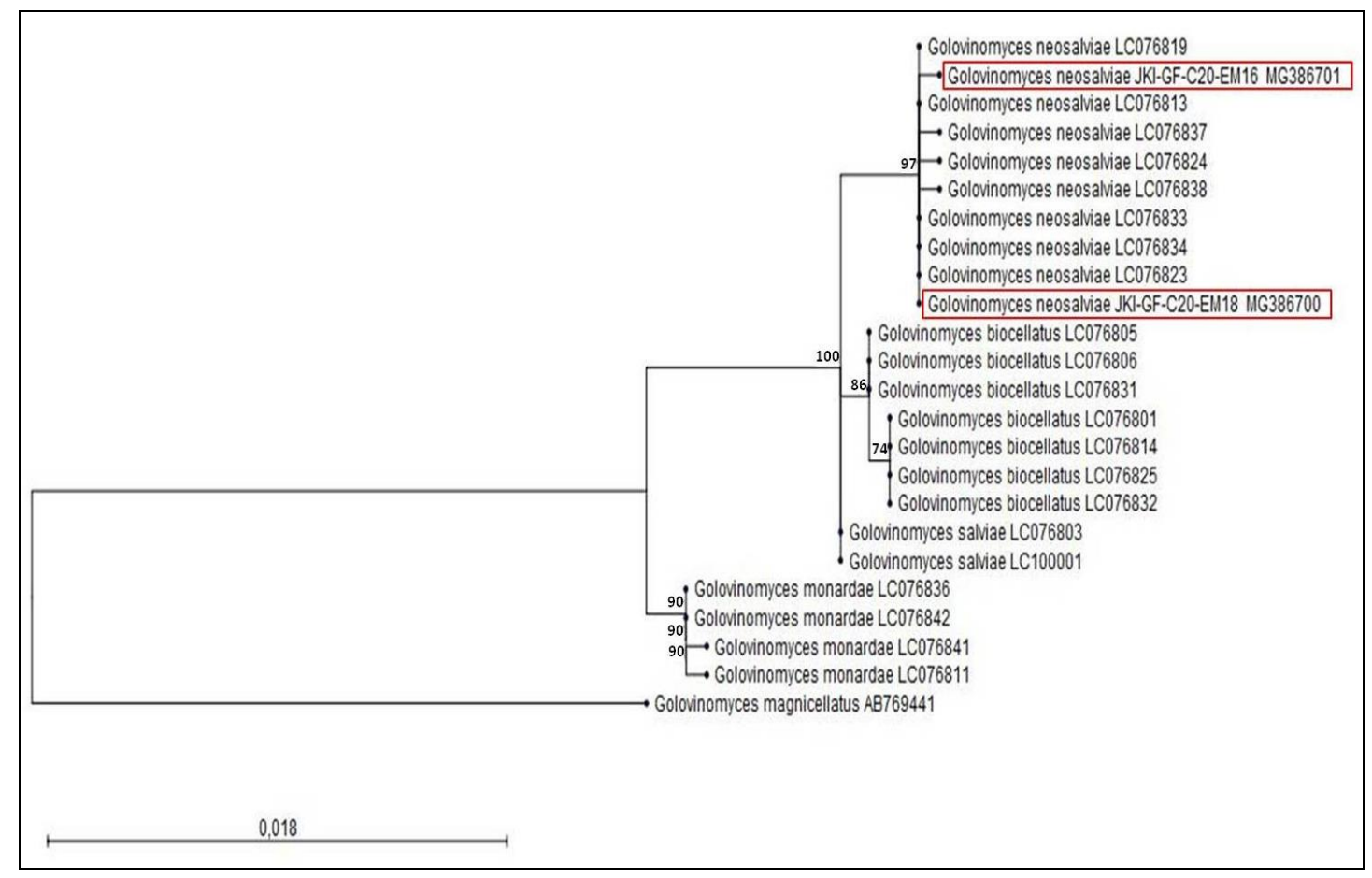

Fig. 1 - Phylogenetic analysis (combined data of ITS1, 5.8S rRNA, ITS2 and 28S rRNA complete and partial sequences) for the isolates JKI-GF-C20-16 and JKI-GF-C20-18 including 24 selected sequences from the genus Golovinomyces. Bootstrap support values for maximum likelihood higher than $70 \%$ are defined as above the nodes. The tree is rooted to Golovinomyces magnicellatus (AB769441). The isolates JKI-GF-C20-16 and JKI-GF-C20-18 are framed in red.
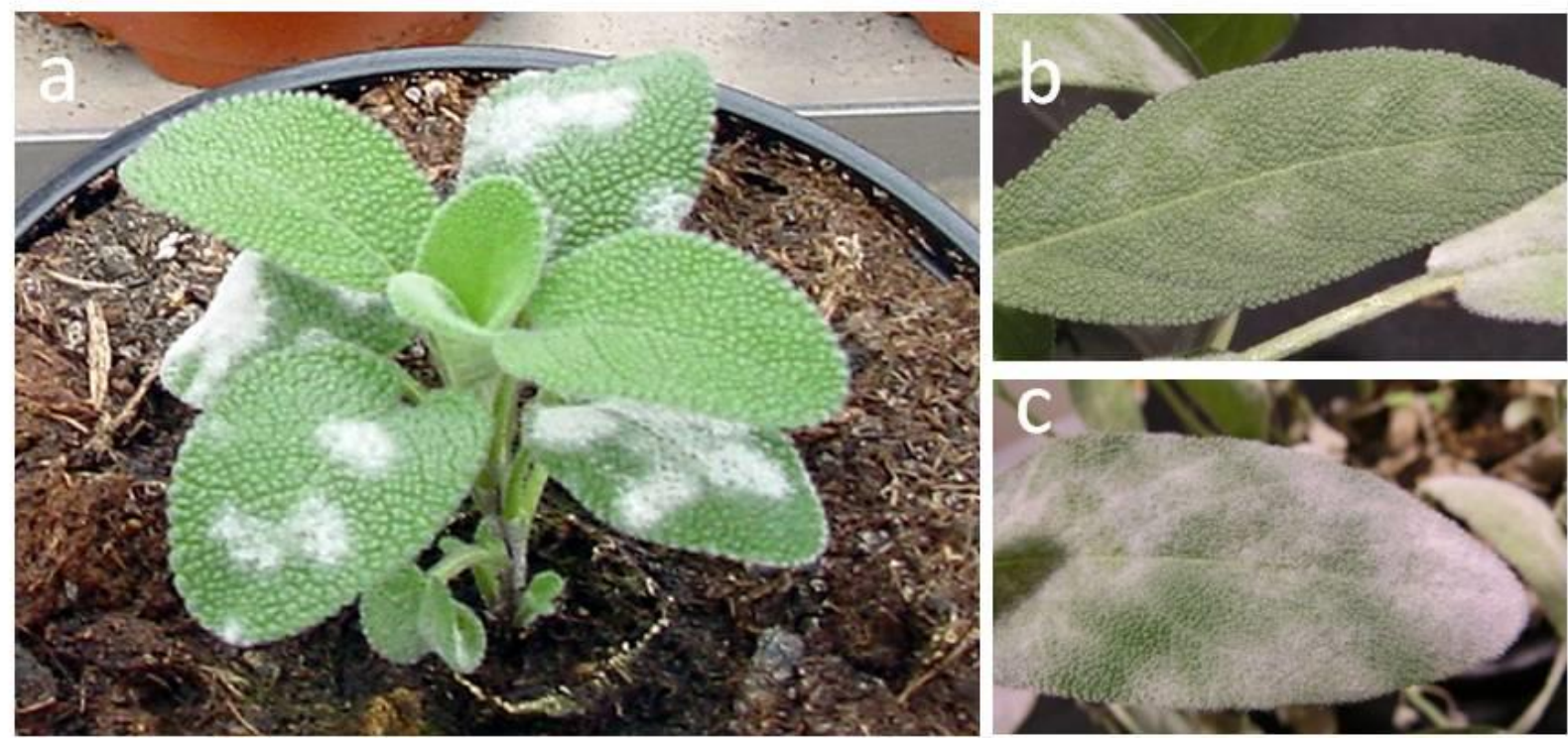

Fig. 2 - Golovinomyces neosalviae JKI-GF-C20-EM18 on Salvia officinalis. a Naturally infected S. officinalis 'Culinaria'. b-c Inoculated leaves of S. officinalis 'Cleres'. 
Table 2 Morphological characteristics of Golovinomyces neosalviae isolates JKI-GF-C20-EM16 and JKI-GF-C20-EM18 on Salvia officinalis and published data for G. neosalviae on the same host. Differing features are highlighted in grey.

\begin{tabular}{|c|c|c|c|}
\hline Characters & $\begin{array}{l}\text { G. neosalviae } \\
\text { JKI-GF-C20-EM16 } \\
\text { This study } \\
\end{array}$ & $\begin{array}{l}\text { G. neosalviae } \\
\text { JKI-GF-C20-EM18 } \\
\text { This study } \\
\end{array}$ & $\begin{array}{l}\text { G. neosalviae } \\
\text { Scholler et al. } 2016\end{array}$ \\
\hline \multicolumn{4}{|l|}{ Mycelium } \\
\hline Hyphae & Hyaline, thin-walled, smooth & Hyaline, thin-walled, smooth & Hyaline \\
\hline Width & $2-7 \mu \mathrm{m}$ & $3-7 \mu \mathrm{m}$ & $4-7 \mu \mathrm{m}$ \\
\hline \multicolumn{4}{|l|}{ Appressoria } \\
\hline Abundance & Not frequently & Not frequently & Not frequently \\
\hline Shape & Nipple-shaped & Nipple-shaped & $\begin{array}{l}\text { Nipple-shaped to slightly } \\
\text { lobed }\end{array}$ \\
\hline \multicolumn{4}{|l|}{ Conidiophores } \\
\hline Length & $\begin{array}{l}(240-) 250-340-475(>800) \\
\mu \mathrm{m}\end{array}$ & $\begin{array}{l}(150-) 170-290-490(>740) \\
\mu \mathrm{m}\end{array}$ & $140-400 \mu \mathrm{m}$ \\
\hline Width & $8-13 \mu \mathrm{m}$ & $8-14 \mu \mathrm{m}$ & $(8-) 9-13(-14) \mu \mathrm{m}$ \\
\hline Foot cell length & $(41-) 44-51-58(-65) \mu \mathrm{m}$ & $(31-) 57-67-77(-127) \mu \mathrm{m}$ & \\
\hline $\begin{array}{l}\text { Distance of basal } \\
\text { septum to the base }\end{array}$ & $2-25 \mu \mathrm{m}$ & $4-23 \mu \mathrm{m}$ & $7-25 \mu \mathrm{m}$ \\
\hline Branched & Yes & Yes & No \\
\hline Shoulder-like structures & Yes & Yes & No \\
\hline \multicolumn{4}{|c|}{ Conidia } \\
\hline Conidiogenesis & Catenescent & Catenescent & Catenescent \\
\hline $\begin{array}{l}\text { Shape } \\
\text { Length }\end{array}$ & $\begin{array}{l}\text { Doliiform, rarely ellipsoid } \\
(30-) 34-42-49(-53)\end{array}$ & $\begin{array}{l}\text { Doliiform, rarely ellipsoid } \\
(28-) 34-39-47(-59)\end{array}$ & $\begin{array}{l}\text { Doliiform to limoniform } \\
(29-) 33-44(-48)\end{array}$ \\
\hline Width & $(17-) 19-24-29(-30)$ & $(17-) 19-22-25(-26)$ & $(20-) 22-26(-28)$ \\
\hline Length:width ratio & $1.2-2.7$ (average 1.7 ) & $1.3-3.3$ (average 1.8 ) & $1.2-2.2$ (average 1.7 ) \\
\hline Fibrosin bodies & No & No & No \\
\hline \multicolumn{4}{|l|}{ Germ tube } \\
\hline Position & Subapical & Subapical & Subapical \\
\hline Shape & Non to one-septate & Non to one-septate & Non to one-septate \\
\hline Termination & $\begin{array}{l}\text { Simple, club-shaped or } \\
\text { lobed appressorium }\end{array}$ & $\begin{array}{l}\text { Simple, club-shaped or } \\
\text { lobed appressorium }\end{array}$ & $\begin{array}{l}\text { Simple or club-shaped } \\
\text { appressorium }\end{array}$ \\
\hline \multicolumn{4}{|l|}{ Chasmothecia } \\
\hline & Not found & Not found & Found \\
\hline
\end{tabular}

Interestingly, single or multiple branching of the conidiophores was observed predominantly in the middle of the colonies. Branches could arise from the foot cell or any following cell (Figs 3b, c, $4 \mathrm{~b}, \mathrm{c})$. Furthermore shoulder-like swellings were often observed mostly at the upper third of the cells or above (Figs 3d, 4d).

Conidia were distinctly doliiform, rarely ellipsoid. The exact measurements for both isolates are listed in Table 2. The conidial surface (SEM) exhibited reticulate ridges (Fig. 5a). Fibrosin bodies were not observed. Germ tubes were inserted subapically (Fig. 5b). They were non-septate or one-septate, measuring $20-120 \times 3.5-7 \mu \mathrm{m}$, terminating in a simple or club-shaped or a lobed appressorium when formed in a moist-chamber. Chasmothecia were not observed on naturally infected plants in the field and inoculated leaves/plants in climate chambers.

\section{Discussion}

Several powdery mildew species were reported to infect Salvia spp., amongst them Neoerysiphe galeopsis, Leveillula duriaei, and representatives of the Golovinomyces biocellatus complex (Braun \& Cook 2012, Scholler et al. 2016). In a phylogenetic analysis of the genus Golovinomyces on the basis of ITS and 28S rRNA sequences, Takamatsu et al. (2013) placed specimens isolated from Saliva spp. in two different subclades of the G. biocellatus clade. Scholler et al. (2016) expanded and consolidated analyses and knowledge of the phylogeny and taxonomy of 
the G. biocellatus complex, redescribed G. salviae, and introduced $G$. neosalviae as a new species. G. salviae infected S. pratensis and S. nemorosa whereas G. neosalviae infected S. officialis and $S$. lavandulifolia.

Radisek et al. (2012) found a powdery mildew on S. officinalis in Slovenia. On the basis of morphological features and an ITS sequence, they assigned the isolate to G. biocellatus. However, a re-evaluation of the sequence (GenBank accession No. JQ340358) by the authors with recently published sequences proved the assignment to $G$. neosalviae. Interestingly, conidiophores described for this Slovenian isolate were much shorter than those described by Scholler et al. (2016).
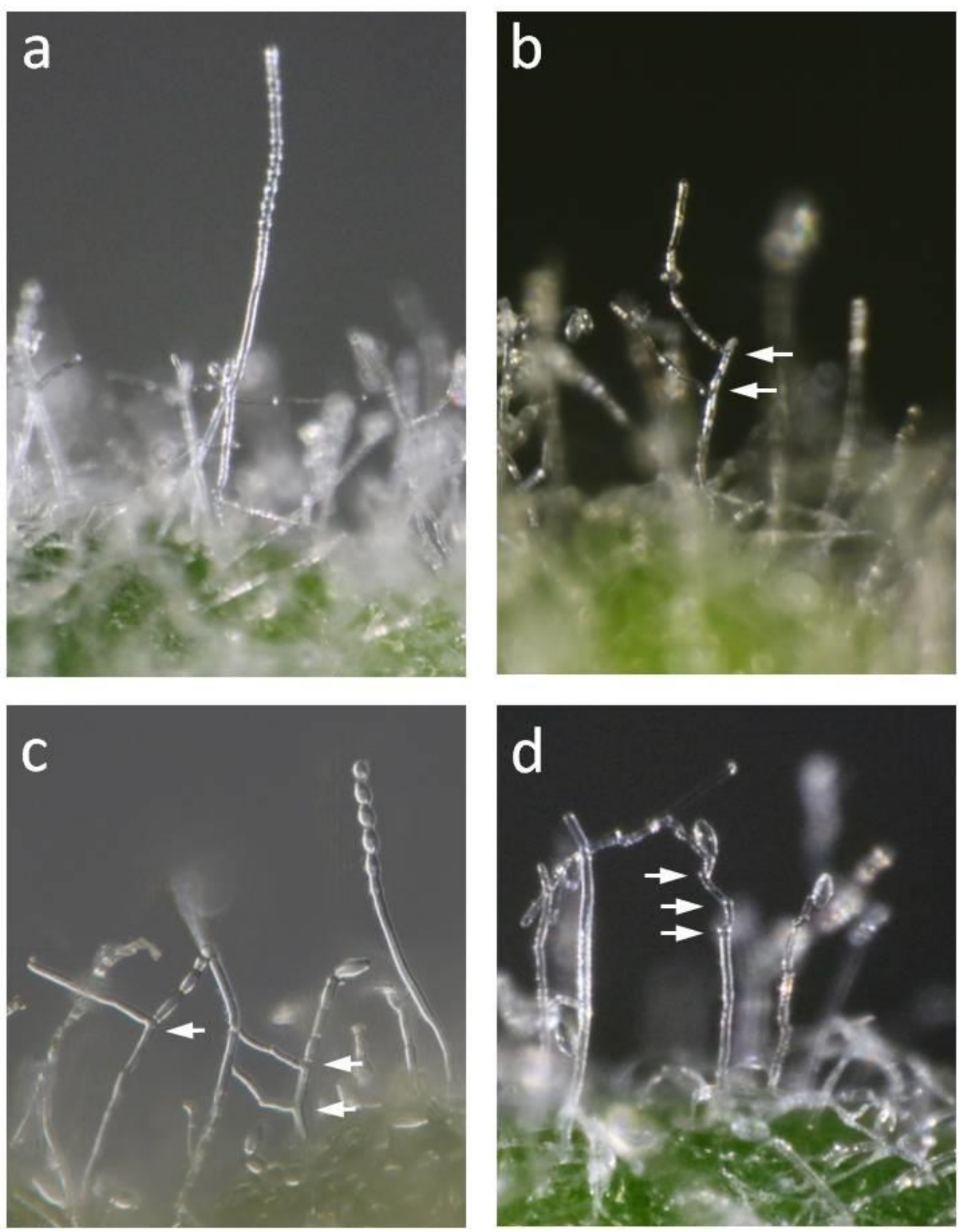

Fig. 3 - Conidiophores of Golovinomyces neosalviae on Salvia officinalis 'Cleres' (epiphyllous). a Long conidiophore (JKI-GF-C20-EM18). b-c Branched conidiophores (arrows) (JKI-GF-C20EM18, JKI-GF-C20-EM16). d Conidiophores with shoulder-like swellings (arrows) (JKI-GF-C20EM18). 

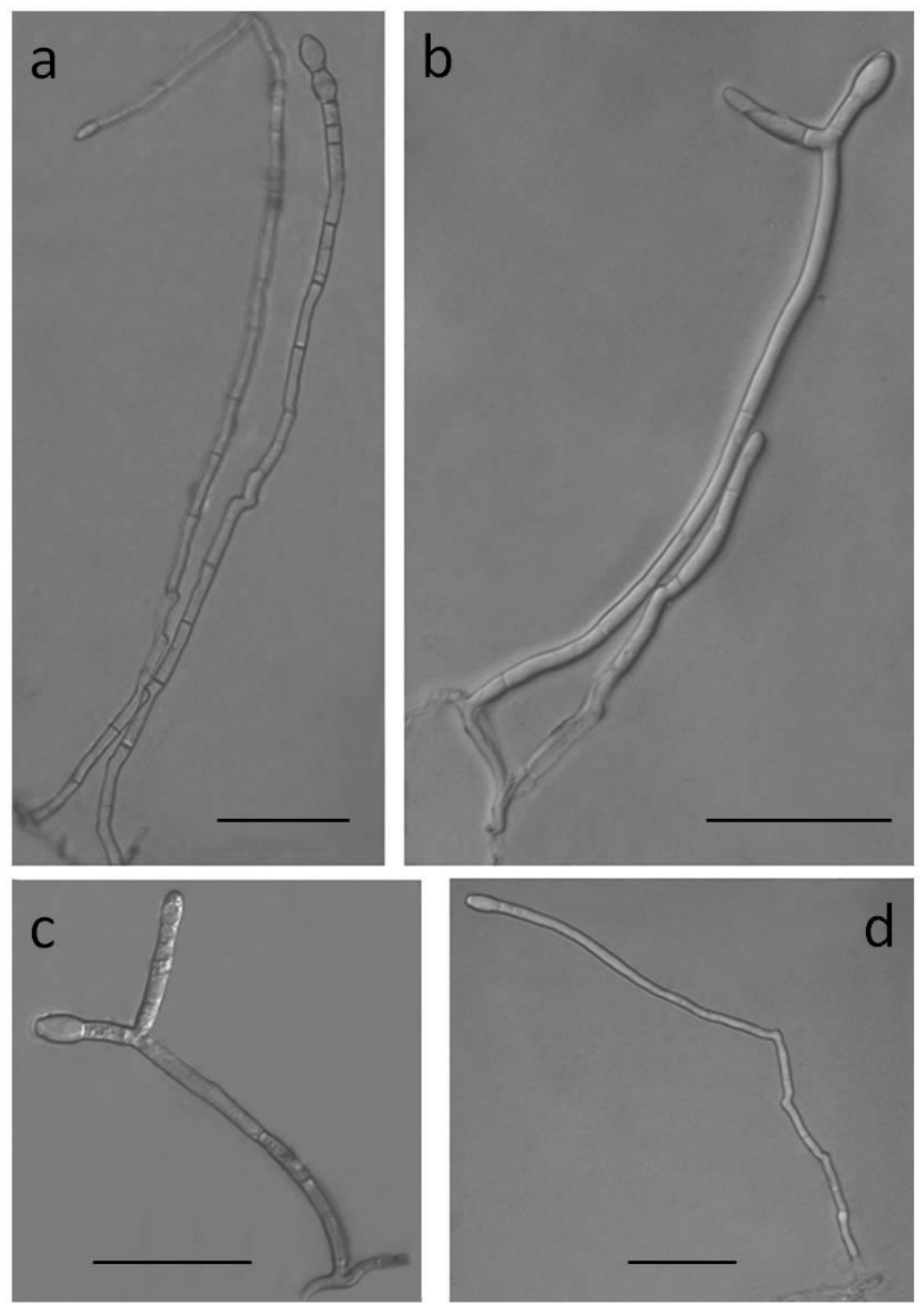

Fig. 4 - Conidiophores of Golovinomyces neosalviae on Salvia officinalis 'Cleres' (epiphyllous). a Long conidiophores (JKI-GF-C20-EM16). b-c Branched conidiophores (JKI-GF-C20-EM16, JKI-GF-C20-EM18). d Conidiophore with shoulder-like swellings (JKI-GF-C20-EM18). The background was removed with Adobe Photoshop to clarify the relevant features of the conidiophores. Bars $=100 \mu \mathrm{m}$.
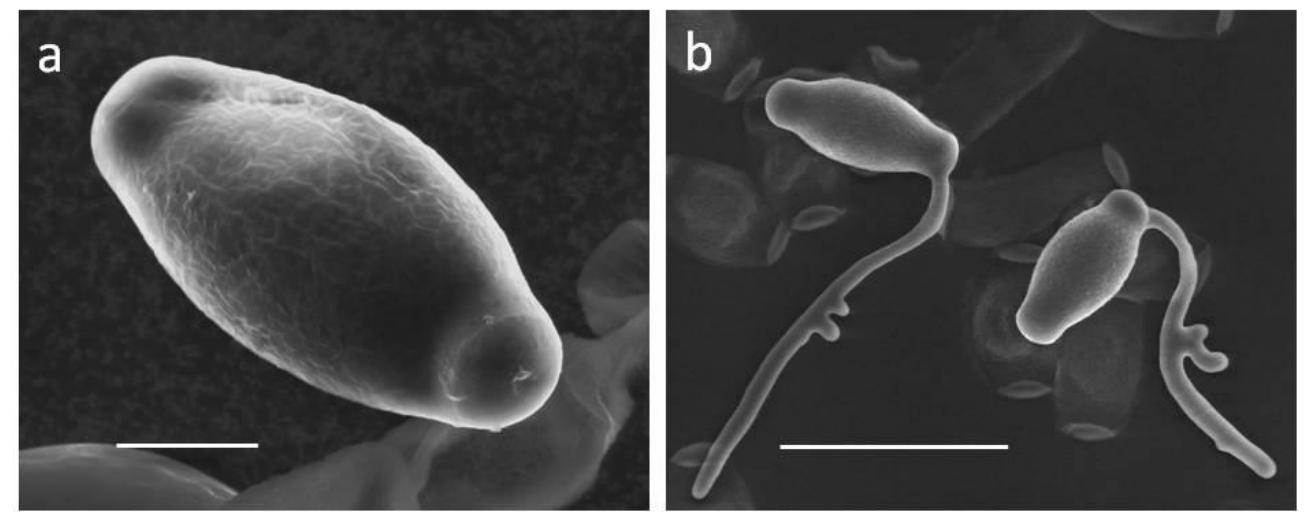

Fig. 5 - Conidia of Golovinomyces neosalviae JKI-GF-C20-EM18. a Net-like ridges of the conidial surface and septum. b Subapically inserted germ tubes. The contrast and brightness were adjusted with Adobe Photoshop to clarify the relevant features. - Bars $=10 \mu \mathrm{m}$ (a), $50 \mu \mathrm{m}$ (b). 
None of the powdery mildews mentioned above showed the typical characteristics of the two strains described in this work, which to some extent developed extremely long and sometimes branched conidiophores that often developed shoulder-like swellings. These morphological features were observed in epi- and hypophyllous colonies on different Salvia cultivars (data not shown). Other morphological features like size and shape of appressoria and conidia were comparable to the description of Scholler et al. (2016).

Molecular examinations showed identical sequences of the ITS-28S rRNA (1nt exchange) for both isolates, which clustered with G. neosalviae sequences from GenBank, proving the assignment to this species. Therefore, it is concluded that the branching of conidiophores is just a morphotypical variation/modification.

The ecological significance of morphotypes with branched conidiophores is poorly understood to date. Branched conidiophores are not uncommon in asexual morphs of the genus Leveillula [Oidiopsis] (Palti 1971, Braun \& Cook 2012), but do not or only very rarely occur in species of the genus Erysiphe. Riaz et al. (2013) described a morphotype of the grape powdery mildew Erysiphe necator that predominantly developed branched conidiophores. The colonies of that morphotype spend more energy in producing branches than mature conidia which the authors discuss as a competitive disadvantage. This might be a reason why branched conidiophores of powdery mildews are not often found in nature. The branching type in the grape vine powdery mildew is not quite identical with that in $G$. neosalviae since the ramification appeared at the base of the first conidium that independently started making conidia. In G. neosalviae, the ramification may happen on different levels of the conidiophores, from the foot-cell or any following cell, and independent of the conidiation. Furthermore, the conidiophores of the new morphotype of $G$. neosalviae are characterized by a certain degree of geniculation, which is not developed in branched conidiophores of Erysiphe necator (Riaz et al. 2013).

A monitoring of G. neosalviae on S. officinalis would provide information on the abundance of branched conidiophores. Furthermore, a direct comparison of both morphotypes with and without branched conidiophores concerning virulence and further phytopathological features might shed light on the relevance of this feature.

\section{Acknowledgements}

The authors thank Olaf Redlin (Klostergärtnerei, Riddagshausen) and Mascha Hoffmeister (Institute for Epidemiology and Pathogen Diagnostics, JKI, Braunschweig) for providing infected Salvia officinalis plants and Elvira Dressler and Petra Mitschke for excellent technical assistance.

\section{References}

Anon. 2014 - 100 Jahre eigener Salbeianbau 1914 - 2014. Bombastus-Werke AG, Germany, http://www.bombastus-werke.net/pdf/Faltblatt\%20100JahreSALBEI-E-020414nie.pdf (accessed 22 February 2018).

Braun U, Cook RTA. 2012 - Taxonomic Manual of the Erysiphales (Powdery Mildews). CBSKNAW Fungal Biodiversity Centre, Utrecht, The Netherlands.

Cabrera MG, Vobis G, Álvarez RE. 2010 - Powdery mildew on Salvia officinalis in Corrientes, Argentina. Mycosphere 1(4), 289-291.

Frank HM. 1990 - Zur einheitlichen Präsentation der Ergebnisse von Sporenmessungen. Boletus $14,36-42$.

Hirose S, Tanda S, Kiss L, Grigaliunaite B et al. 2005 - Molecular phylogeny and evolution of the male powdery mildew (Sawadaea, Erysiphaceae) inferred from nuclear rDNA sequences. Mycological Research 109(8), 912-922. DOI: 10.1017/S0953756205003527

OEPP/EPPO 2016 - PM7/129(1) DNA barcoding as an identification tool for a number of regulated pests. Bulletin OEPP/EPPO 46(3), 501-537. DOI: 10.1111/epp.12344.

Palti J. 1971 - The Leveillula mildew. Botanical Review 54, 423-535. 
Radisek S, Ferant N, Jakse J, Javornik B. 2012 - First report of powdery mildew caused by Golovinomyces biocellatus on common sage (Salvia officinalis) in Slovenia. Plant Disease 96(7), 1065. DOI: 10.1094/PDIS-01-12-0010-PDN.

Riaz S, Braun U, Lejkina I, Gubler WD, Waker MA. 2013 - Report of a new grape powdery mildew morphotype with branched conidiophores. Plant Pathology \& Quarantine 3(1), 1927. DOI: $10.5943 / \mathrm{PPQ} / 3 / 1 / 4$.

Scholler M, Schmidt A, Siahaan SAS, Takamatsu S, Braun U. 2016 - A taxonomic and phylogenetic study of the Golovinomyces biocellatus complex (Erysiphales, Ascomycota) using asexual state morphology and rDNA sequence data. Mycological Progress 15, 1-13. DOI: $10.1007 / \mathrm{s} 11557-016-1197-5$

Takamatsu S, Kano Y. 2001 - PCR primers useful for nucleotide sequencing of rDNA of the powdery mildew fungi. Mycoscience 42, 135-139. DOI: 10.1007/BF02463987

Takamatsu S, Matsuda S, Grigaliunaite B. 2013 - Comprehensive phylogenetic analysis of the genus Golovinomyces (Ascomycota: Erysiphales) reveals close evolutionary relationships with its host plants. Mycologia 105(5), 1135-1152. DOI: 10.3852/13-046

Zaracovitis C. 1965 - Attempts to identify powdery mildew fungi by conidial characters. Transactions of the British Mycological Society 48(4), 553-558. 